\title{
Mehmet Akif Ersoy'un Poetikası
}

\section{Aykut Nasip KELEBEK*}

\section{$\ddot{O} z$}

Şairlerin şiir anlayışları hakkında derli toplu sonuçlara ulaşabilmek için onların poetik metinlerine başvurma zorunluluğu bulunmaktadır. Büyük bir kısmını 20. yüzyılın ilk çeyreğinde yayımladığı Safahat adlı yedi ciltlik şiir külliyatıyla Türk edebiyatında kendisine önemli bir yer edinen Mehmet Akif Ersoy, şiirin ve edebiyatın meseleleri üzerine de düşünüp metinler üretmiş bir şairdir. Mehmet Akif'in poetik metinlerinde divan şiirine birtakım eleştiriler yönelttiği, sanat sanat içindir ile sanat toplum içindir anlayışlarını sorgulayıp bunlardan ikincisini öne çıkardığı ve gerçeklik sorunsalı üzerinde durduğu görülmektedir. Bu makalede bu meseleler üzerinden gidilerek Mehmet Akif'in şiir anlayışı hakkında sonuçlara ulaşılmaya çalışılacaktır. Elbette bunlar, Mehmet Akif’le başlayıp biten meseleler değildir. Batı edebiyatında gerçeklik sorunsalı ve sanat sanat için mi yoksa toplum için midir ikilemi üzerine geniş bir literatür bulunmaktadır. Ayrıca bu meseleler Tanzimat döneminden itibaren Türk şair-yazarları arasında da uzun uzadıya tartışılmıştır. Bu incelemede, bütün bu veriler ışı̆̆ında, Mehmet Akif'in Tanzimat dönemindeki edebiyat anlayışlarıyla ve özellikle de Namık Kemal'le arasındaki süreklilik ilişskisi üzerinde de durulacaktır.

Anahtar Kelimeler: Mehmet Akif Ersoy, poetika, divan şiiri, toplum, gerçeklik.

* Doktora Öğrencisi, İstanbul Medeniyet Üniversitesi, Türk Dili ve Edebiyatı Bölümü, İstanbul, Türkiye.

Elmek: aykutnasipkelebek@gmail.com

http://orcid.org/Orcid: 0000-0003-3361-3762.

Geliş Tarihi / Received Date: 15.08.2021

Kabul Tarihi / Accepted Date: 10.10.21 


\title{
Mehmet Akif Ersoy's Poetics
}

\begin{abstract}
In order to reach tidy conclusions about the poets' understanding of poetry, there is an obligation to refer to their poetic texts. Mehmet Akif Ersoy, who has an important place in Turkish literature with his seven-volume poetry corpus titled Safahat, most of which was published in the first quarter of the 20 th century, is a poet who also thought about the issues of poetry and literature and produced texts. It is seen that Mehmet Akif made some criticisms to divan poetry in his poetic texts, questioned the understandings of art is for art and art is for society, and emphasized the second of these, and focused on the problem of reality. In this article, it will be tried to reach conclusions about Mehmet Akif's understanding of poetry by going through these issues. Of course, these are not issues that started and ended with Mehmet Akif. In Western literature, there is a large literature on the problem of reality and the dilemma of whether art is for art or for society. In addition, these issues have been discussed at length among Turkish poets and writers since the Tanzimat period. In this study, in the light of all these data, the continuity relationship between Mehmet Akif's understanding of literature in the Tanzimat period and especially with Namık Kemal will be emphasized.
\end{abstract}

Keywords: Mehmet Akif Ersoy, poetics, divan poetry, society, reality. 


\section{Giriș}

Aristo'nun Poetika adlı kitabından bu yana sanat ve edebiyat tarihinin belli başıı kavramları arasında yer alan ve antik çağdan modern döneme gelene dek çeşitli anlam değişikliklerine de uğrayan "poetika" kavramı, günümüzde kimi çalışmalarda edebiyat bilimi ve sanat kuramı gibi anlamları içeriyor olsa da, daha ziyade şairlerin şiir sanatına ve kendi şiir anlayışlarına ilişkin düzyazı metinlerini karşılamak için kullanılmaktadır. Orhan Okay Poetika Dersleri adlı kitabında poetika kavramının geçmişte "estetik" kavramına benzer bir anlam yüklenmesine rağmen, günümüzde neredeyse sadece şiir alanında kullanıldığına işaret eder. Ona göre "poetika, bugünkü kullanılışıyla (...) şiir sanatı üzerine teoriler demektir.” (2013: 15) Klasik dönem şairleri de şiir sanatı üzerine konuşmuşlardır, mesela Fuzuli’nin Türkçe divanının ön sözünde, ilimsiz şiirin temelsiz duvar hükmünde olacağına dair ileri sürdüğü düşünceler bir poetik yaklaşım denemesi olarak kaydedilebilir. Gelgelelim klasik dönem şairlerinin şiir sanatı üzerine müstakil metinler üretmek gibi bir alışkanlık sahibi olduğundan da söz edilemez. Şairlerin şiir üzerine düşüncelerini derli toplu metinlerle ifade etmeleri 19. yüzyılla birlikte hız kazanmış bir etkinliktir, öyle ki birçok modern şair deneme ve makale türlerinin hacimlerini de aşarak poetikalarını müstakil kitaplarla ortaya koymuştur. Percy Bysshe Shelley'nin 1821'de yazdığı ve ölümünden sonra, 1840'ta yayımlanan Şiirin Bir Savunması metni; Edgar Allan Poe'nun hayatının sonlarına doğru yazdığı ve ölümünden bir yıl sonra yayımlanan Örneklerle 'Şiirin Illkesi' metni; Vladimir Mayakovski'nin 1926 tarihli Şiir Nasıl Yapılır'1 ve Rainer Maria Rilke'nin yine 1926 tarihli Genç Şaire Mektuplar'ı bu bağlamda anılabilir. Söz konusu zaman diliminde poetika üretimindeki bu artışa, Selçuk Çıkla da “Poetika teriminin anlam alanı XIX. yüzyıla yaklaştıkça çoğunlukla 'şiir' türüyle ilgili olmaya başlamış ve son iki yüzyılda şair ve yazarlar ya içinde 
bulundukları bir akımın sanat görüşlerini ya da bireysel olarak sanat, edebiyat ve şiir görüşlerini poetik metinlerde dile getirmişlerdir." (2015: 19) cümleleriyle işaret etmektedir. Elbette bir şairin salt şiirlerinden yola çıkılarak da şiir anlayışına ilişkin kayda değer verilere ulaşılabilir, hatta birçok şairin şiir sanatı hakkında düşüncelerini şiirleri içerisinde dile getirdikleri de görülür. Ancak düzyazıyla üretilen modern poetikalar; şaire şiirin çeşitli unsurlarına, şiirin diğer edebi türler ve sanat dallarıyla ilişkisine ve gerek geçmiş dönemin gerekse de çağının şairlerine ilişkin düşüncelerini açıklaması için oldukça geniş bir alan sunar. Modern şairlerin poetikalarını yazma gerekçeleri şairden şaire değişkenlik gösterir. Orhan Okay'ın yine Poetika Dersleri kitabında incelediği Ahmet Haşim, Necip Fazıl Kısakürek ve Orhan Veli poetikalarına bu bağlamda göz atılabilir. Ahmet Haşim, "Şiirde Mâna" başlığıyla yayımlayıp sonradan Piyâle kitabına "Şiir Hakkında Bazı Mülahazalar" başlığıyla aldığı poetikasını; Dergâh dergisinde yayımlanan "Bir Günün Sonunda Arzu" başlıklı şiirine getirilen eleştiriler üzerine kaleme almıştır. Burada doğrudan şairin kendi şiir anlayışını savunma arzusu ön planda görünür. Orhan Veli “Garip" başlıklı poetikasını, Oktay Rifat ve Melih Cevdet Anday'la birlikte ortak kitap olarak yayımladığı Garip kitabının ön sözü olarak kaleme almıştır. Edebiyat tarihine sonradan Garip adıyla yerleşecek akımın manifestosu olarak kabul edilen bu poetika; şairin sadece kendi şiirine ilişkin yargılarını açıklamakla kalmaz, aynı zamanda mevcut şiirin yıkılıp yenisinin kurulmasının gereğini de vurgular. Necip Fazıl Kısakürek ise "Poetika" başlıklı sonradan Çile kitabına dahil edeceği poetikasını, ilkin Büyük Doğu dergisi sayfalarında “İdeologya Örgüsü” başlı̆ğ altında yayımlamıştır. Necip Fazıl'ın poetikasının dünya görüşünün çok kesin bir uzantısı olduğu ve bu poetikanın üretiminde ideolojik motivasyonun ciddi bir rol oynadığı söylenebilir. Orhan Okay'ın kitabına dahil etmediği başka şairlere bakıldığında ise poetika üretimine dair şaşırtıcı örneklerle karşılaşılabilir. Cumhuriyet döneminin önde gelen şairlerinden Cahit Sıtkı Tarancı müstakil bir poetika yazmamış olsa da onun bir başka Cumhuriyet dönemi şairi Ziya Osman Saba'ya gönderdiği ve sonradan 
Ziya 'ya Mektuplar adlı kitapta bir araya getirilen mektupları; edebiyat araştırmalarında poetika olarak kabul görmektedir. (Yavuz 2012: 75) Gerçekten de bu mektuplarda şairin hem kendi şiirine hem de döneminin şiiri üzerine son derece çarpıcı düşünceleri bulunmaktadır. Ahmet Hamdi Tanpınar'ın "Antalyalı Genç Kıza Mektup” adlı mektubu ve Günlüklerin Işı̆̆ııda Tanpınar'la Baş Başa adlı kitapta bir araya getirilen günlükleri ise şiir sanatı hakkında müstakil olarak kaleme aldığı metinlerle bir arada değerlendirilebilmektedir. Ne gerekçeyle yazılmış olursa olsun, poetikalar; şairin biçim-öz, imge, kafiye, söz sanatları, gelenek, modernizm, ideoloji vs. kavram ve meseleler hakkında düşüncelerini öğrenmek için kritik önemde metinlerdir.

Geçmişten günümüze kaleme alınan birçok poetikanın zevk-fayda ikilemi etrafinda oluşturulduğu söylenebilir. Bu ikilemin kökenlerine bakmak için de Batı edebiyatının erken dönem poetikalarına eğilmek gerekebilir; çünkü iki işlev arasında gerilimin ilk yansımaları ve bu gerilimi ortadan kaldırmaya yönelik çözüm önerileriyle antik dönem poetikalarında karşılaşmak mümkündür. Michel Jarrety Poetika adlı kitabında, Latin şair Horatius'un Ars Poetica adlı eserinde zevk ve fayda ikilemine yaklaşımını şöyle anlatır: "Horatius'a göre, yarar zevkin önüne geçmemelidir, çünkü beceriksizce yaratılmış ve çekici olmayan bir yapıt etkileyemez; böylece, şiir ancak mükemmel olduğu takdirde yararlı olabilir." Jarrety, Horatius'un "Yararlı olanı hoş olanla karıştırın, okuyucuyu hem büyülemeyi hem eğitmeyi bilen herkesin beğenisini toplar” şeklindeki formülasyonunun Klasisizm'in gerekliliği haline geldiğini belirtir. (2010: 29-30) Zevk ve fayda arasındaki ikilem ortadan kalkmamış, modern dönemde daha da ciddi kutupların ortaya çıkmasına yol açmıştır. Edebi eserde zevki önceleyenlerin kabaca "sanat sanat içindir", faydayı önceleyenlerin ise yine kabaca "sanat toplum içindir" tasnifi altında değerlendirildiği görülür. Bu ikilemin yansımalarını modern Türk edebiyatının erken aşamalarında da tespit etmek mümkündür: 1839'da Tanzimat'ın ilanıyla birlikte resmen Batılılaşma dönemine giren Osmanlı Devleti'nde, 
edebiyat kurumu da süreç içerisinde Batı'dan birtakım edebi türleri, öze ve biçime dair birtakım unsurları ve belki de asıl mühimi yaklaşım biçimlerini bünyesine dahil ederek Batılılaşma yoluna girmiştir. Bu dönemde şiir sanat1 üzerine metin üretme etkinliği yoğunluk kazanmaya ve poetik polemikler edebiyat gündeminin merkezinde yer edinmeye başlamıştır. Tanzimat döneminin poetik tartışmalarının göbeğinde de dönemin öncü şahsiyetlerinden Namık Kemal bulunmaktadır. Şiirden romana edebi ürünleri, yayın faaliyetleri ve sosyal ve siyasi eylemleriyle yaşadığı dönem boyunca kamuoyunda büyük yankılar yaratan Namık Kemal, şiir ve genel olarak edebiyat üzerine görüşleriyle de polemiklere yol açan ve yaşadığı dönemi biçimlendiren bir şahsiyet olmuştur. Namık Kemal'in "Tahrîb-i Harabat", "Mukaddime-i Celal" ve "Lisân-1 Osmânî’nin Edebiyatı Hakkında Bazı Mülâhazâtı Şâmildir" gibi edebiyat üzerine metinleri onun poetik hamleleri olarak görülebilir. Namık Kemal bu metinlerinde çok sert bir divan şiiri aleyhtarlığ geliştirmiş, edebiyatı toplumun ahlaki gelişiminde araç olarak öne sürmüş, gerçekçiliği 1srarla savunmuş ve edebi dili konuşma diline yaklaştırma arzusunu dile getirmiştir. (Göçgün 2014: 91) Kenan Akyüz, “1866'da Tasvir-i Efkâr'da çıkan 'Lisân-1 Osmanînin Edebiyyâtı Hakkında Bazı Mülâhazatı Şâmildir' adlı uzun makalesinde ileriye sürdüğü Divân Edebiyatı hakkındaki küçültücü düşüncelerini, Hârâbat'ı tenkid maksadıyle yazdığı Tahrîb-i Hârâbat (1876) ve Ta'kîb (1886) adlı eserlerinde daha şiddetle savunur." cümleleriyle, Namık Kemal'in divan edebiyatı hakkındaki olumsuz yaklaşımlarını ömrünün sonuna dek sürdürdüğünü belirtmektedir. (1995: 85) Namık Kemal'in eski edebiyata hücum etmesi, eski edebiyatın gerçeklikle ilişkisine karşı bir pozisyon almasından kaynaklanmaktadır. Ahmet Hamdi Tanpınar bu durumu şu şekilde açıklar: "Nâmık Kemal'in eskiye hücum ettiği noktalar onu evvelâ hakikate, sonra da tabiata yahut tabiat-1 eşyaya uygun bulmamasıdır. O eskilerin edebiyat anlayışına ve hayal sistemine hücum eder. Ona göre eski edebiyat insanla hayat arasında tam bir münasebet kuramamıştır. Ufku dardır; ancak onun bittiği yerde duygularımızın kâinatı ve hayatın türlü manzarası başlar." (2010: 379) Namık 
Kemal'in bu yaklaşımları, bu incelemenin konusu olan Mehmet Akif'in poetikasında da çok ciddi ölçüde kendini yeniden gösterecektir. Tanzimat döneminin bir başka önemli şairi Ziya Paşa da yine "Şiir ve İnşa" makalesi ve $\mathrm{Ha}$ rabat antolojisindeki ön sözüyle poetika sınıfina dahil edilebilecek metinler kaleme almıştır. "Şiir ve İnşa”" makalesinde Osmanlı şiiri Baki ve Nef'î'den gelen kaside, gazel ve mesnevi midir yoksa Nedim'le Vâsıf'ın şarkıları mıdır gibi sorularla eski şiiri sorgular ve sonuç olarak bunların hiçbirinin Osman11 şiiri olmadığını, İran yoluyla Araplardan alınmış şeyler olduğunu söyler. (Ercilasun 2007: 298) Bu makalede Namık Kemal'le aynı çizgide durarak, divan şiirine sert eleştiriler getiren Ziya Paşa, Harabat antolojisinin girişinde bu defa divan şiirini övmeye başlayınca Namık Kemal de Tahrib-i Harabat'1 kaleme alarak ona karşı hücum etmiştir. Bu tablo, poetikaların ortaya çıkışında polemiklerin ne ölçüde etkili olabileceğini göstermektedir. Bütün bu verilerin ardından, Tanzimat'ın ilk kuşak şairlerinden Namık Kemal'in ve "Şiir ve İnşa” makalesindeki görüşleriyle Ziya Paşa'nın zevk-fayda ikileminde faydadan yana saf tuttuğu tespit edilebilir. Zaten Namık Kemal'in Ziya Paşa'ya tepki göstermesinin sebeplerinden biri olarak Ziya Paşa'nın "Harabat" mukaddimesiyle söz konusu ikilemde faydadan ziyade zevke öncelik tanımaya başlamasının etkili olduğu savunulabilir. Tanzimat'ın ikinci kuşak şairlerinde ise sanat toplum içindir anlayışı arka plana atılıp sanat sanat içindir anlayışı öne çıkarılmaya başlanmıştır ki Recaizade Mahmud Ekrem'in, özellikle de Talim-i Edebiyat gibi poetikası addedilebilecek eserleri rahatlıkla bu yönelimin örneği sayılabilir. Fazıl Gökçek, "Zerrattan şümusa kadar her güzel şey şiirdir" diyen Recaizade Mahmud Ekrem'in, Namık Kemal'in toplum meseleleri ile içeriğini genişlettiği şiiri tabiatta var olan ve insanın beğenisine hitap eden her şeye teşmil ettiğini söyler. Ona göre Recaizade, güzelliği öne çıkararak aynı zaman Horace'tan bu yana üzerinde durulan "zevk" ve "fayda" ikileminde zevkten yana saf tutmaktadır. (2014: 21) Şu çok kısa aktarımlardan bile Tanzimat sonrası Türk şiirinin poetik malzeme açısından son derece zengin bir alan olduğu görülebilmektedir. Bu makalede poetikası incelenecek olan 
Mehmet Akif Ersoy ise Tanzimat dönemi figürlerinin yavaş yavaş geri çekilip yerlerini Servet-i Fünun dönemi şahsiyetlerine bıraktığı bir dönemde edebiyat sahnesine çıkmıştır. Dolayısıyla Mehmet Akif' in poetikasının, söz konusu dönemlerde ortaya atılan düşüncelerin ve yaşanan tartışmaların süreğinde değerlendirilmesi bir zorunluluktur. Edebiyat üzerine metinlerinde Namık Kemal'e saygısını açıkça dile getiren, sanatın toplum yararına kullanılması gerektiğini ve hayal yerine gerçeğin anlatılmasını tartışmaya yer bırakmayacak kesinlikle savunan ve Secaatin Tural'ın ifadesiyle "toplumcu gerçekçiliğe oldukça yakın bir şair portresi” (2014: 25) çizen Akif; bu tavrını edebiyat üzerine metinleriyle sınırlı tutmamış, "Hayır, hayâl ile yoktur benim alışverişim. / İnan ki: Her ne demişsem görüp de söylemişim. / Şudur cihanda benim en beğendiğim meslek: / Sözüm odun gibi olsun; hakîkat olsun tek!” (Ersoy 2013: 590-592) gibi sıklıkla referans gösterilen mısralarında görülebileceği üzere şiirlerine de yansıtmıştır. Bununla birlikte incelemenin odağında, şairin edebiyat üzerine metinleri bulunacaktır.

1873 doğumlu olan Mehmet Akif, edebiyat dünyasına 20. yüzyılın hemen başında dahil olmuştur. Orhan Okay Akif'in herkesçe bilinen şiirlerinin Safahat'ında toplananlar olduğunu ve bunların da 1904'ten sonra yazıld1ğını veya dergilerde yayımlandığını belirtir. 1873 doğumlu şair; ilk Safahat'1 1911'de yayımladığı dikkate alındığında, ilk şiirini 31, ilk şiir kitabını 37 yaşında yayımlamıştır. (2019: 87) Mehmet Akif Ersoy, bu çalışmada incelenecek olan "Plan", "Îcâd, Mevzû", "Muhayyileyi İşletmek", "Âhenk", "Tasvîr" ve "Teşbîh" gibi edebiyat üzerine metinlerini de yine 20. yüzyıl başlarında, 1909-1910 aras1 süreçte, Sirât-ı Müstakîm ve Sebîlü'r-Reşâd dergilerinde yayımlamıştır. Fevziye Tansel, Akif'in bu makaleleri kaleme almasında Dârülfünun'da Edebiyat-1 Umûmiye müderrisi olmasının etkili olduğunu ifade eder. (2021: 62) Akif'in adı geçen yazıları da dahil olmak üzere bu makalede değerlendirilecek olan edebiyat üzerine metinlerine, Yusuf Turan Günaydın tarafından hazırlanan Kavâid-i Edebiyye isimli kitabından ulaşılımıştır. 
Adı anılan makaleler Akif'in divan şiiri, Tanzimat şiiri, Batı edebiyatı ve şiirin teknik meseleleri hakkında görüşlerini ana hatlarıyla açığa çıkarıyor olsa da bu makalede Akif'le ilgili biyografik eserlere de sıklıkla atıfta bulunulacaktır. Sanatçıların yakınında bulunmuş kişilerin aktardığı hatıralar, hele de Akif gibi edebiyat üzerine nispeten az metin kaleme almış isimlerin poetikalarının aydınlatılması hususunda büyük önem taşımaktadır. Bu çalışmada da Akif' in yakın dostlarından Mithat Cemal Kuntay'ın Mehmet Âkif Ersoy / Hayatt-Seciyesi-Sanatı ve Hasan Basri Çantay'ın Âkifname adlı çalışmalarına yeri geldikçe başvurulacaktır.

\section{Doğu'dan Yana}

Mehmet Akif, Tanzimat döneminin devamında, Osmanlı Devleti'nin çözülüş sürecinde ortaya çıkmış bir şairdir. Tanzimat'la birlikte resmen Batılılaşmaya başlayan Osmanlı Devleti'nde, okur-yazar çevrelerin belki de en önemli tartışma konusu Batılılaşmanın kendisidir. Neredeyse bütün entelektüeller Osmanlının nasıl Batılılaşması gerektiği, Batılılaşırken Doğulu unsurların bu sürece nasıl dahil edileceği, iki farklı medeniyete ait özelliklerin nasıl bir potada eritileceği gibi hususlar üzerine uzun uzun kafa yormuş; söz konusu düşüncelerini sadece makalelerinde değil roman ve hikâye gibi edebi türlerinde de etraflıca işlemeye çalışmışlardır. İslamcı bir şair olarak Mehmet Akif'in Batılılaşma hususunda, döneminin birçok aydınının aksine bir hayli mesafeli ve birçok yerde tepkisel bir tutum takındığı kolaylıkla söylenebilir. O, Doğu-Batı ikileminde merkezi ağırlığı Doğu'ya vermiş, bu yönüyle Cumhuriyet sonrasında belirginleşen Necip Fazıl Kısakürek ve Sezai Karakoç gibi kendinden sonraki şairlerin de öncülügünü üstlenmiştir. Akif; "Batı'nın ahlakını dışarıda bırakalım, tekniğini alalım” gibi bir yaklaşım geliştirmiş, bunu şiirlerinde de açıkça dile getirmiştir. Akif'in, Safahat'ın ikinci kitabr olan Süleymaniye Kürsüsünde'den alıntılanan mısraları bu bağlamda kabul edilebilir: 
Alınız ilmini Garb'ın, alınız san'atini;

Veriniz hem de mesâinize son sür'atini.

Çünkü kâbil değil artık yaşamak bunlarsız;

Çünkü milliyyeti yok san'atin, ilmin; yalnız,

İyi hâtırda tutun ettiğim ihtârı demin:

Bütün edvâr-1 terakkîyi yarıp geçmek için,

Kendi “mâhiyyet-i rûhiyye"niz olsun k1lavuz.

Çünkü beyhûdedir ümmîd-i selâmet onsuz. (2013: 488)

Mehmet Akif'e göre Doğulular Batı'nın ilmini ve sanatını almalı, bunlardan yararlanmalıdır; çünkü ilmin ve sanatın milliyeti yoktur. Ancak Doğulular "mâhiyyet-i rûhiyye"lerini, yani bu bağlamda kendi dini ve kültürel özelliklerini korumalıdırlar, bunlar korunmaksızın ümmetin selametinin bir anlamı yoktur. Arap ve Acem lisanlarıyla uğraşacak zamanda değiliz, medeni milletlerin dillerini öğrenelim diyenlere "Sizin bu teklifiniz tıpk1 'Coğrafya kitaplarından Asya, Afrika kıt'alarını artık kaldıralım.' demeye benziyor." şeklinde cevap verdiklerini bildiren Akif; Doğu-merkezciliğini şu cümleleriyle açıkça dışa vurur: "A kuzum, bizim o mütemeddin akvâmın arâzîsinde bir karış toprağımız yok. Bize orada ne ektirirler ne de biçtirirler. Biz Asya'da ekeceğiz, Asya'da biçeceğiz.” (2016: 72) Bunlara ilaveten Akif, Doğulu kalmak suretiyle Batı'dan yararlanılması gerektiği yolunda tezini sadece yukarıda gösterildiği şekilde şiirlerinde değil, edebiyat üzerine metinlerinde de işlemiştir. Akif, Doğululuğu esas alır, bununla birlikte Doğu'yla birlikte Batı medeniyetinin layıkıyla tanınmasını da zorunluluk sayar: "Bana öyle geliyor ki 'Ne varsa Şarkta vardır' diyenler yalnız Garbı değil, Şark’ı da bilmiyorlar. Nitekim 'Ne varsa Garbda vardır' davâsını ileri sürenler yalnız Şark’ı değil Garbı da tanımıyorlar.” (s. 99) Mithat Cemal Kuntay’ın aktarımlarına bak1larak, Akif'in bu satırlarında ileri sürdüğü görüşleri yaşamında da uyguladığ rahatlıkla savunulabilir: "Âkif iki adamı sevmezdi: Avrupa'ya takılıp memleketinin toprağına iğreti basanı... Bir de kaşlarına kadar Şarka batarak gözü Avrupa'y1 görmeyeni..." (2020: 292) 


\section{Sanat Sanat İçindir'e Karşı}

Girişte, 20. yüzyılda çok sayıda şairin poetika yazdığ 1 ve yine birçok şairin de ardında poetika olarak değerlendirilmeye son derece müsait çeşitli metinler bıraktığı belirtilip Ahmet Haşim, Necip Fazıl ve Orhan Veli gibi şairlerin poetikalarından kısaca bahsedilmişti. Hem bu şairlerin poetikalarında hem sonraki kuşaklardan Ahmet Hamdi Tanpınar, İlhan Berk, Sezai Karakoç, Cemal Süreya, Hilmi Yavuz ve İsmet Özel gibi şairlerin poetikalarında Fransız sembolist şairlerine atıflarla karşılaşılmakta; bu şairlerin referans gösterilmek için olsun karşı çıkılmak için olsun sıklıkla anıldığı görülmektedir. Söz konusu poetikalarda Fransız sembolistlerinden en çok da Charles Baudelaire (1821-1867), Stéphane Mallarmé (1842-1898), Paul Verlaine (1844-1896), Arthur Rimbaud (1854-1891) ve Paul Valéry (1871-1945) isimlerinin zikredildiği söylenebilir. Mehmet Akif'in edebiyat üzerine yazılarında Alphonse de Lamartine (1790-1869), Victor Hugo (1802-1885), Emile Zola (1840-1902) ve Alphonse Daudet (1840-1897) gibi Fransız edebiyatının çeşitli şair-yazarlarından sıkça bahsedilse de yukarıda adı geçen sembolistlerden herhangi bir şekilde söz açılmamıştır. Akif; Yahya Kemal ve Ahmet Haşim'le birlikte Türk şiir kamuoyunun yakından tanımaya başladığı sembolist şairleri yakından tanımamış, tanımış olsa bile önemsememiş olabilir. Çünkü "Sanat sanat içindir" anlayışıyla derin bağlara sahip olan Fransız sembolizmi, şiiri kendi içerisinde başlayıp biten bir etkinlik kabul etmiş ve toplumsal meselelere girişme gereğini pek duymamıştır. Oysa Akif, hem şiirleri ve şiir üzerine yazılarından hem de kendisini yakından tanıyanların aktarımlarından kolaylıkla çıkarılabileceği üzere, "Sanat toplum içindir" anlayışından yana saf tutmaktadır. Akif'i en çok sinirlendiren sözlerin "Sanat sanat içindir.", "Sanatın gayesi sanattır." ve "Sanat mukayyet değildir." gibi sözler olduğunu söyleyen Hasan Basri Çantay; onun bu hususta bir öğrenci topluluğuna yaptığı konuşmayı da şu şekilde aktarmaktadır: "Şarkta, garpta yetişmiş meşâhîrin eserleri tedkik edilince görülür ki, her biri her yazdığı eserinde mutlaka bir gaye takip etmiştir. Demek 
ki sanat mutlak değildir. Madem ki 'sanat sanat içindir' düsturunun ortaya atılmasına rağmen hiçbir edib, hiçbir şair bir maksat gözetmekten kendini kurtaramıyor; o halde bu düstur artık iflâs etmiş demektir. Kezâlik, madem ki bu düsturların hükmüne tebaiyyet edilemiyor, sanat mukayyet kalıyor, öyleyse sanatı birtakım hasis emellere, sefil ve müstekreh maksatlara alet edinmektense ulvî, pâk, asil, necip duygulara, düşüncelere vasıta kılmak elbette daha makul bir hareket olur." (2020: 104) Mehmet Akif'in burada sanatçının "bir maksat gözetmekten kendini kurtaramıor" olduğuna ve buradan hareketle sanat sanat içindir anlayışının çökmüş bulunduğuna ilişkin görüşünü pek çok modern edebiyat kuramcısı da paylaşmaktadır. Son dönemin önemli edebiyat eleştirmeni ve kuramcılarından Terry Eagleton; edebiyat ile ideolojiden karşılıklı ilişki kurulabilecek iki ayrı fenomenmiş gibi bahsetmenin gereksiz bir şey olduğunu ve edebiyatın toplumsal iktidar sorunlarıyla çok sıkı bağlantılarının bulunduğunu söyler. Ona göre, "Edebiyat, kelimenin miras anlamıyla, bir ideolojidir." (2014: 36)

Mehmet Akif Ersoy şiirinin toplumsal boyutlarına Orhan Okay da sık sık temas etmektedir. Akif' in poetikasının özeti olarak "Hayır hayal ile yoktur benim alışverişim / İnan ki her ne demişsem görüp de söylemişim / Budur cihanda benim en beğendiğim meslek / Sözüm odun gibi olsun, hakikat olsun tek." şeklinde mısralarını gösteren Okay, Akif'in lirik şiiri bilen bir usta şair olmasına rağmen kendi iradesiyle şiirini milletinin meseleleri emrine verdiğini kaydeder. (2019: 196) Sanat toplum içindir anlayışını savunan diğer sanatçılar gibi Akif de gerçekliğe ve dış dünyanın gerçekçi bir üslupla yansıtılmasına büyük önem vermiştir. Sezai Karakoç, "Mehmed Âkif, Yahya Kemal ve Necip Fazıl” başlıklı yazısında, Mehmet Akif'in şiirindeki gerçekçiliğe, “Âkif' in bakışı sıhhatli ve kahramanın bakışı gibidir. Realizmde ondan daha ileri giden şairimiz yoktur." (2016: 68) cümleleriyle işaret eder. Akif'e göre, "Muhayyileyi İşletmek" başlıklı yazısı referans alınırsa; hakikat, hayat ve şahitlik her edebi eserin esas şartları arasında bulunur. Sanatçı hiç yoktan bir mevzu icat 
edeceği zaman bile işe doğallık vermek için hakikati kendisine dayanak alır; bu nedenle de sanatçı gerçek hayattan alınmış olup mevzuyu genişletmeye yarayacak olay ve durumlara başvurmalı, gördüğü muhitlerden ve incelediğ şahıslardan yararlanmalı ve gerçek hayat ile hayal dünyası arasında bir uyum oluşturmaya çalışmalıdır. Eserinde bir ruh hali, bir şahsiyet arayan sanatçı; yakından tanıdığı adamları almalı ve onları oldukları gibi göstermelidir. Akif’e göre Batı'da yetişen meşhur sanatçılar hep bu şekilde başarılı olmuşlardır. (2016: 29-30) Mehmet Akif; gerçekliğe uygun, açıkça anlaşılabilir bir edebi eser tahayyül etmektedir. Onun bu gerçekçi tutumu sıkça tartışılmıştır. Mithat Cemal Kuntay, Akif üzerine kitabında, sanatta "karanlığı" sevdiğimizi, eserleri anlamak yerine tatmamız gerektiğini, belirsizliğin en güzelleştiği yerin sanat olduğunu, ilk bakışta "saçma" fakat iyi bakınca "mucize" dediğimiz esrarengizliğin sanatı yapan şey olduğunu söyler ve ardından Akif' in şiirinde bu esrarengizliğin olmadığını, şiirine karanlığı sokmadığını belirtir. (2020: 309) Mithat Cemal, şiire açıkça sembolistlerin perspektifinden bakmaktadır. Sembolistler şiirde belirsizliği savunmuş, şiirin ancak sınırlı sayıda entelektüel tarafından anlaşılabilir bir sanat olarak inşa edilmesi gerektiğini savunmuştur. Onların bu yaklaşımları Türk şiirinde Ahmet Haşim, Ahmet Hamdi Tanpınar, Asaf Halet Çelebi ve İlhan Berk gibi şairler tarafından da benimsenmiştir. Örneklendirmek gerekirse, Ahmet Haşim, "Şiir Hakkında Bazı Mülahazalar" başlıklı metninde, "Şiirin bir müşterek lisan olmasını isteyenlerin vâhi hayaline tahakkuk imkânı temenni etmekle beraber, şimdiye kadar hiçbir büyük şairin, mahdut bir insan tabakası hâricinde anlaşılmış olduğu iddia edilemeyeceği kanaatindeyiz.” (2011: 68) cümleleriyle şiir sanatının muhatap olduğu okur topluluğunu kesin bir dille sınırlandırmaktadır. Esasen Ahmet Haşim gibi Sembolizm etkisindeki şairlerle Mehmet Akif'in şiir anlayışı arasındaki fark1, Mehmet Kaplan da çok özlü bir şekilde anlatmaktadır: "Haşim akşam karanlığında meçhule doğru uzanan yollardan, sadece cemiyetin değil varlığın da dışına çıkmak istiyordu. Akif, onun tam zıddına, her şeyin vazıh olarak göründüğü bir öğle güneşi altında hayatın, gürültülü, boğucu ve alelade hayatın 
içine girer." (1998: 174) Kaplan'ın açıkça ortaya koyduğu üzere, Sembolizm etkisindeki şairler duyularla algılanabilir dünyadan kaçarak kendi içlerinde başka bir gerçekliğin peşine düşerlerken; Mehmet Akif, duyularla algılanabilir dünyanın tam da merkezinden konuşmaya çalışmaktadır. Sembolizm etkisindeki şairlerin kapalı şiir dillerine karş11ık o, şiirde açık ve anlaş1ır bir dilden yana tavır almaktadır. Öte yandan Mithat Cemal Kuntay Mehmet Akif'in sadece şiirine değil dini algılayış biçimine de mesafeli görünmektedir. Akif' in Müslümanlığı "güzel” diye değil "doğru” diye sevdiğini söyleyen Kuntay; Akif' in “tekke Müslümanı” değil “cami Müslümanı” olduğunu söyler. (2020: 258) Mithat Cemal Akif’ in Acem Müslümanlığına geçen tasavvufu sevmediğini de belirtir, zaten Akif' in ileride üzerinde durulacak divan şiiri aleyhtarlığ da bu şiirin omurgası konumunda olan tasavvuf aleyhtarlığıyla içe içe geçmiş durumdadır. Bunlara ilaveten, sembolizm takipçisi şairlerin Akif'e bakış açısını göstermek adına Tanpınar'ın Akif hakkında bir soruşturmaya verdiği cevaplar da aktarılabilir. Akif' in ölümünün hemen ardından düzenlenen bir ankette, kendisine yöneltilen "Akif' in edebiyata teknik bakımdan hizmeti olmuş mudur?" sorusuna "Mehmet Akif'in Türk edebiyatına değiştirici kıymetler getirdiğini zannetmem." şeklinde cevap veren Tanpınar; Akif'e eleştirilerinde önemli ölçüde sembolizmin paradigmalarıyla hareket eder. Sembolist şairler dinin kurallarını çok önemsemez ve gündeme getirmezken mistisizmle derin bağlar kurar, dış gerçekliğe sırt çevirerek ruhsal yaşantıya eğilir ve realizmin kalıplarıyla aralarına mesafe koyarlar. Tanpınar'ın Akif'e getirdiği şu eleştiriler, Akif' in sembolizmin tam karşısında hareket eden bir şair olmasıyla ilişkilidir: "Şurasını da söyleyeyim ki Akif hiçbir zaman büyük bir din şairi de olamamıştır. Çünkü onda büyük din şairlerinin farikası olan mistik hamle yoktur, o kuru bir ehl-i sünnet şairidir ve dini de biraz imparatorluk ile karıştırır, onun âdeta tutucu maddesi hâlinde görür. Mizacı itibarıyla mistisizmden, panteizmden çok uzaktı. Onun içindir ki mesela bir Yunus veya Nesîmî cinsinden büyük kanat darbeleriyle bizi zahirî realitenin gayrı olan bir realiteye, iç âlemine, Rabb'in hakiki arşı olan insan gönlüne götüremez. Onlar ne kadar 
birleştirici ise, Akif o kadar ayırıcıdır. En ziyade muvaffak olduğu tarafları hayatın iş manzaralarıdır. Garip bir realizmi vardır, fakat bu realizm dediğim gibi çok kurudur." (2019: 355)

\section{Divan Şiirine Karşı}

Mehmet Akif, Doğu edebiyatının Batı edebiyatı karşısında geri kaldığı görüşünü ileri sürmektedir. Sanat eserinin bir "plan" dahilinde inşa edilmesini savunduğu "Plan" başlıklı yazısında geçen "Osmanlı üdebâsını Garblılardan bu kadar geride bırakan esbâbın en birincisi, şüphe yoktur ki, 'plan' meselesidir." cümlesi de onun bu düşüncesinin çok açık göstergesidir. Akif, her şeyiyle başından sonuna dek planlanmış sanat eseriyle herhangi bir plana bağlı kalmaksızın üretilmiş eser arasındaki fark üzerine düşünmenin bile gereksiz olduğunu söyledikten sonra, divan şairlerini plansız davrandıkları gerekçesiyle eleştirir ve divan şiirinin de "plan dinler takımdan" olmadığını ifade eder: "Eski şâirlerimiz böyle muntazam plan dâhilinde hareket etmeyi hâtıra getirmiş olmadıklarından başka bizim tarz-1 kadîm şiirimiz de, doğrusu pek öyle plan dinler takımdan değil idi!” Mehmet Akif eski şairleri eleştirirken yeni şairlerin ise "plana lüzumu kadar değilse de az çok ehemmiyet ver"diklerini söyler, bu da onun Tanzimat sonrası Türk şiirindeki yeniliklere destek verdiğinin kanıtı sayılabilir. Akif aynı yazısında 17. yüzyıl Fransız düşünürlerinden Pascal'ın "Bir şeyin yalnız güzel olması kâfi değildir, mevzua bigâne olmaması da şarttır. Mevzû öyle ister ki; ne bir şey eksik olsun, ne bir şey fazla." cümlesine referansla Batıl1ların edebi eserde plana büyük özen göstermelerine karşılık bizim divanlarımızda -hem de Batılıların nadiren yazabilecekleri ölçüde- çok kıymetli mısralar bulunmasına rağmen bu mısraların belli bir tertipten yoksun olduğunu dile getirir. Akif’e göre Fuzuli’nin “Leyla ile Mecnun”u yüksek nitelikte şiirler içermesine rağmen şair efsaneyi kaleme almaya başlamadan önce eserine nasıl başlayacağını, nelerden bahsedeceğini, nasıl bir neticeye ulaşacağını planlamamıştır; eser edebi kıymetten değilse de bütünlükten yoksundur. Üstelik bu problem sadece Fuzuli değil Nâbî, Yahyâ ve Şeyh Gâlib 
gibi diğer büyük divan şairleri için de geçerlidir. Akif, bu eleştirilerinden sonra Türk edebiyatının Batı edebiyatını örnek alması gerektiğini savunur: "Efendiler, bizim Garb edebiyâtından istediğimiz, daha doğrusu edeceğimiz istifâde onların bütün hissiyâtına hattâ bütün âdâtına tercümân olarak bu millet-i merhûmeye anlayamayacağı, anladığı sûrette de zevk alamayacağı birtakım u'cûbeler okutmak; yâhûd halkın zevk-i behîmîsini okşayacak, zâten sallanıp duran ahlâk-1 umûmiyyeyi temelinden yıkacak numûneler göstermek değildir. Gözümüzü açmalı, aklımızı başımıza almalıyız da edebiyâtı insâniyete hâdim bir fenn-i müstakil telâkkî ederek teâlîsine onlar gibi çalışmalıyız; şerâitini câmi bir eser-i edebî nasıl oluyor, ne gibi hâzırlıklar istiyor, buralarını onlardan öğrenerek muntazam, muayyen planlar, metîn, muhkem usûller takîb etmeliyiz." (2016: 23) Akif' in bu yaklaşımları, daha önce aktarılan "Alınız ilmini Garb'ın, alınız san'atini; (...) / Kendi “mâhiyyet-i rûhiyye”niz olsun kılavuz." mısralarının sosyal hayattan poetikaya uyarlanmış hali kabul edilebilir. Sosyal hayatta ilerleme adına Batı'nın ilminin alınıp ahlakının dışarıda tutulması gerektiğini savunan Akif, poetikada da Batıdan edebi tekniklerin alınıp toplumun ahlaki yapısına zarar verebilecek içerik unsurlarının dışarıda tutulması gerektiğini ileri sürer. Akif'e göre şiirde Batılıların şekil düzleminde izlediği plan ve programlardan yararlanılacak; ancak içerik, Doğunun ahlaki anlayışıyla oluşturulacaktır. Akif'in divan şiirine getirdiği bu eleştiriler daha önce Namık Kemal tarafından da ifade edilmişti. Ömer Faruk Akün'e göre; Türk edebiyatı, şiirde konu ve fikir bütünlüğünü ön planda tutan Batı edebiyatı örneklerini tanıdıktan sonra divan edebiyatındaki gazellere eleştirel bir perspektifle yaklaşmaya başlamıştır. Akün; divan edebiyatını eleştirilmesi en kolay noktalarından ele aldığını belirttiği Namık Kemal'in, gazeli bu yönüyle, içine her şeyin rastgele tıkıldığı bir parça bohçasına benzettiğini de hatırlatır. (1994: 406) Akif, yine divan şiirine eleştiriler getirdiği "Tasvîr” başlıklı yazısında ise eski şairlerin gözle görülene ait gerçekçi tasvirlere hiç önem vermediklerini belirtir ve bunun sorumlusu olarak da şairlerimizin İran edebiyatına eklemlenmelerini gösterir. Eski şairlerimiz İran şiiriyle uğraştıkları kadar eski 
Arap şiiriyle ilgilenmiş olsalar ya da Batı'nın edebi eserlerine bigane kalmasalar Türk edebiyatında da tasvire dair güzel eserler bulunacağını iddia eden Akif; divanlarımızdaki tasvirlerin baştan başa hayali olduğunu; bahar, hazan, gurub, tulu gibi kudret levhalarının bile etraflıca tasvir edilmediğini; bir Acem şairi baharı nasıl görmek istemişse bizim şairlerimizin de öyle gördüğünü belirtir. (2016: 48) Divan şiirinin kendine ait özellikleri bu çalışmanın sınırlarının dışında kalmaktadır. Ancak yine de Mehmet Akif'in divan şiirine yönelttiği bu eleştirilerde Namık Kemal'den etkilenmiş olduğu söylenebilir. Namık Kemal'in tasavvufi şiirin gerçeklik anlayışıyla giriştiği mücadelenin (2019: 51) bir benzerini Mehmet Akif de vermiştir. Akif'le Namık Kemal arasındaki bu süreklilik ilişkisine Fazıl Gökçek de vurgu yapar: "Bizim edebiyat tarihimiz dikkate alındığında, Âkif’ i, şiir yazmaya başladığı yıllarda edebiyatımıza hakim olan Servet-i Fünun'un şiir ve sanat anlayışından ziyade Tanzimat'ın ilk neslinin, özellikle de Namık Kemal'in edebiyat anlayışına yakın olarak görürüz.” (2014: 55)

\section{Sonuç}

Mehmet Akif'in poetikasının özelliklerini tespit etmek için Tanzimat sonrası Türk şiirinde ortaya konulan eleştiri yazılarını, yaşanan polemikleri ve dönemin kendine özgü şartlarını göz önünde bulundurmak gerekmektedir; çünkü Akif de poetik metinlerini Tanzimat'la beraber gelen yenileşme hareketlerinin gölgesi altında kaleme almıştır. Mehmet Akif'e göre Osmanlı sanatçısı, hem Doğu hem de Batı medeniyetini derinden kavramalı; ama merkezine kendi medeniyetini, yani Doğu'yu almalıdır. Sosyal hayatta Batı'nın ilminin ve kültüründen yararlanılmasını ancak ahlakının dışarıda tutulması gerektiğini savunan Akif, yine edebiyatta da Batılıların tekniğinden yararlanılmasını ancak toplumun ahlakına zarar verebilecek içerik unsurlarına yaklaşılmaması gerektiğini vurgular. Mehmet Akif'in önemli özelliklerinden biri de sanat sanat içindir anlayışına cephe açıp ısrarla sanat toplum içindir anlayışını savunmuş olmasıdır. Ona göre ne yaparsa yapsın toplumsal bağlamından kopmayı 
başaramayan edebiyat, toplumun ahlaki gelişiminde vasıta olmalı, insanları doğru yola teşvik etmelidir. Elbette, kendisine bu doğrultuda işlevler yüklenen bir edebiyat, gerçekçi bir üslupla inşa edilecektir. Akif de sanat toplum içindir anlayışının ayrılmaz bir parçası olan gerçekçiliği öne çıarmış, edebiyatta hayalciliğe karşı bir tavır takınmıştır. Mehmet Akif bütün bu yaklaşımlarının bir sonucu olarak divan şiirini belli bir plan ve programdan yoksun olduğu, toplumsal gerçeklerden uzak kaldığı ve İran edebiyatını taklit ettiği gerekçeleriyle sert bir şekilde eleştirmektedir. Bu makalenin başından beri vurguladığımız zevk-fayda ikileminde kesin bir şekilde faydadan yana pozisyon alan Mehmet Akif, bütün bu çerçeve içerisinde Tanzimat'ın ilk kuşak şairlerinden Namık Kemal'in çizgisini takip etmiş olmaktadır. Edebiyat tarihine dair incelemeler, sadece edebi türler arasında değil, poetikalar arasında da süreklilik ilişkisi bulunduğunu kanıtlayan verilerle yüklüdür. 


\section{Kaynakça}

Ahmet Haşim (2011), Bütün Şiirleri, İstanbul: Dergâh Yayınları.

Akün, Ömer Faruk (1994), Divan Edebiyatı, İslâm Ansiklopedisi, İstanbul: TDV İslâm Araştırmaları Merkezi.

Akyüz, Kenan (1995), Modern Türk Edebiyatının Ana Çizgileri 1860-1923, İstanbul: İnkılâp Kitabevi.

Çantay, Hasan Basri (2020), Âkifname Mehmet Akif Ersoy, İstanbul: Erguvan Yayınevi.

Çıkla, Selçuk (2015), Türk Edebiyatında Manzum Poetikalar, Ankara: Akçağ Yayınları.

Eagleton, Terry (2014), Edebiyat Kuramı, İstanbul: Ayrıntı Yayınları.

Ercilasun, Bilge (2007), Ziya Paşa, İstanbul: Akçağ Yay.

Ersoy, Mehmed Âkif(2016), Kavâid-i Edebiyye, Haz: Yusuf Turan Günaydın, İstanbul: Dergâh Yay. Ersoy, Mehmed Âkif (2013), Safahât, İstanbul: Çağrı Yayınları.

Göçü̈n, Önder (2014), Namık Kemal, İstanbul: Akçă̆ Yayınları.

Gökçek, Fazıl (2014), Mehmet Âkif'in Şiir Dünyası, İstanbul: Dergâh Yayınları.

Jarrety, Michel (2010), Poetika, Ankara: Dost Kitabevi Yayınları.

Kaplan, Mehmet (1998), Şiir Tahlilleri 1-Tanzimat 'tan Cumhuriyete, İstanbul: Dergâh Yayınları.

Karaca, Alâattin (2019), İkinci Yeni Poetikası, Hece Yayınları.

Karakoç, Sezai (2016), Edebiyat Yazıları II-Dişimizin Zarı, Diriliş Yayınları.

Kuntay, Mithat Cemal (2020), Mehmet Âkif Ersoy Hayatı-Seciyesi-Sanatı, İstanbul: Alfa.

Okay, Orhan (2019), Mehmed Âkif Kalabalıklarda Bir Yalnız Adam, İstanbul: Dergâh Yay.

Okay, Orhan (2013), Poetika Dersleri, İstanbul: Dergâh Yay.

Tanpınar, Ahmet Hamdi (2019), Hep Aynı Boşluk, İstanbul: Dergâh Yay.

Tanpınar, Ahmet Hamdi (2010), XIX. Asır Türk Edebiyatı Tarihi, İstanbul: Yapı Kredi Yayınları.

Tansel, Fevziye Abdullah (2021), Mehmed Âkif Ersoy Hayatı ve Eserleri, Ötüken Neşriyat.

Tural, Secaattin (2014), Eleştirel Gerçekçilik Bağlamında Mehmet Akif Şiirine Bir Bakış, RumeliDE Dil ve Edebiyat Araştırmaları Dergisi, S. 1, s. 25.

Yavuz, Hilmi (2012), Okuma Biçimleri, İstanbul: Timaş Yayınları. 